\title{
Plants ecotoxicology. A case of low doses and multipollutant exposure
}

\author{
S. Geras'kin ${ }^{1}$, J. Kim², T. Evseeva ${ }^{3}$, A. O udalova ${ }^{1}$ and V. Dikarev ${ }^{1}$ \\ ${ }^{1}$ Russian Institute of Agricultural Radiology and Agroecology, 249020 Obninsk, Russia \\ ${ }^{2}$ Korea Atomic Energy Research Institute, 150 Deokjin-dong, Yuseong-gu, \\ Daejeon 305-353, South Korea \\ ${ }^{3}$ Institute of Biology, Komi Scientific Center, Ural Division RAS, Kommunisticheskaya 28, \\ 167982 Syktyvkar, Russia
}

\begin{abstract}
Results of laboratory, "green-house" and long-term field experiments carried out on different plant species (spring barley, Scots pine, bulb onion and others) to study ecotoxical effects of low doses and concentrations of such common environmental factors as acute and chronic $\gamma$-radiation, heavy metals, pesticides, artificial and heavy natural radionuclides, are presented. Special attention is paid to ecotoxic effects of chronic low dose exposures, synergistic and antagonistic effects of different factors' combined action. The results of long-term field experiments in the 30-km Chernobyl NPP zone and in the vicinity of a radioactive wastes storage facility are discussed. The data presented suggest that the further evolution of investigations in this field would issue in the development of a theoretical bases and practical procedures for environmental protection against radioactivity, taking into account the new experimentally confirmed facts about the presence of such essentially important singularities as the nonlinearity of a dose-effect relationship, radiation-induced genomic instability, phenomenon of radioadaptation, increased probability of synergetic and antagonistic effects of the combined action of different nature factors.
\end{abstract}

\section{INTRODUCTION}

A key question in dealing with contaminated sites is whether, and to what extent ecotoxical effects occur. At severely contaminated sites there are acute effects, but the core problem lies in possible long-term effects of chronic low dose-rate and multi-pollutant exposure. Interaction of contaminants with biota takes place first at the cellular level [1] making cellular responses not only the first manifestation of harmful effects, but also suitable tools for the early and sensitive detection of exposure. It is becoming increasingly clear [2] that cellular alterations may in the long run influence biological parameters important for populations such as growth, health and reproduction. These types of effects are of special concern because they can manifest themselves long after the source of contamination has been eliminated. Therefore, it is the genetic test-systems exactly should be used for an early displaying of the alterations resulting from the human industrial activity. From the practical point of view it is important to know what changes on cytogenetic level can be induced by low doses of ionizing radiation under conditions of single and combined with another factors exposure. Important patterns of biological effects of low-level radiation that don't follow from well-known effects of high doses are:

- nonlinearity of dose response;

- synergetic and antagonistic effects of different factors combined exposure;

- radiation-induced genomic instability;

- phenomenon of radioadaptation.

Let's consider these patterns in more details based on our own experiments. 


\section{NONLINEARITY OF DOSE RESPONSE}

The analysis of experimentally observed cells reactions on low-level irradiation showed [3] that the regularities of cytogenetic disturbances yield in this range are characterized by a sound nonlinearity and have universal character. To corroborate this statement an experiment has been carried out on barley seedlings. From presented in Fig. 1 results it follows that the piecewise linear model fits the data much better than the linear one. It is important, that the improvement of the quality of approximation is not reached by means of the model complicating but achieving a mutual conformity between a biological phenomenon and its mathematical model.

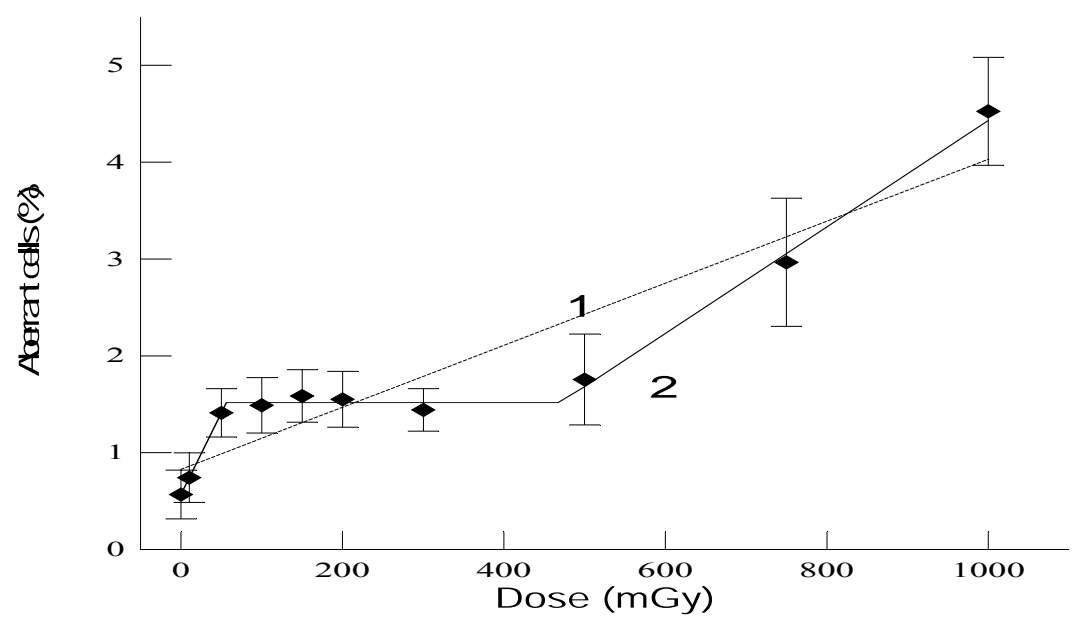

Figure 1. Aberrant cells frequency in barley germs exposed to low radiation doses and its approximation with linear (1) and piecewise linear (2) models.

\section{SYNERGETIC AND ANTAGONISTIC EFFECTS OF DIFFERENT FACTORS COMBINED EXPOSURE}

Contaminants present in nature as mixtures; therefore, interactions between individual compounds may be of importance. Ecotoxicological methods integrate the impacts of all the mutagenic activities in the environment, including synergistic and antagonistic effects. In our studies of combined effect of such frequently occurring agents as acute and chronic $\gamma$-radiation, heavy metals, pesticides, artificial and heavy natural radionuclides on spring barley, bulb onion, spiderwort and other plant species, it was shown that synergetic and antagonistic effects are most often registered at combinations of low doses and concentrations; moreover, these nonlinear effects make a governing contribution to a plant response under certain circumstances. For example, a study of cytogenetic disturbances induction in intercalar meristem cells of spring barley grown on soil contaminated with ${ }^{137} \mathrm{Cs}$ and $\mathrm{Cd}[4]$ has shown (Fig. 2) that the effect of combined exposure exceeds the sum of separate effects as much as $70 \%$. On the contrary, the observed effect at soil pollution by ${ }^{137} \mathrm{Cs}, \mathrm{Pb}$ and pesticides averaged only $50 \%$ from anticipated one proceeding from the additive model. Furthermore, our data $[5,6]$ on genotoxicity assay of water samples from the natural reservoirs formed both in the nuclear explosion epicenter and located near the radium production industry storage cell suggest that substantial biological effects may be caused by metal and radionuclide combined exposure at concentrations below permissible exposure limits for human due to synergic response. Therefore, an application of findings on a separate action to a prediction of combined exposure biological effects is unacceptable and causes essential deviations from experimentally observed data. 


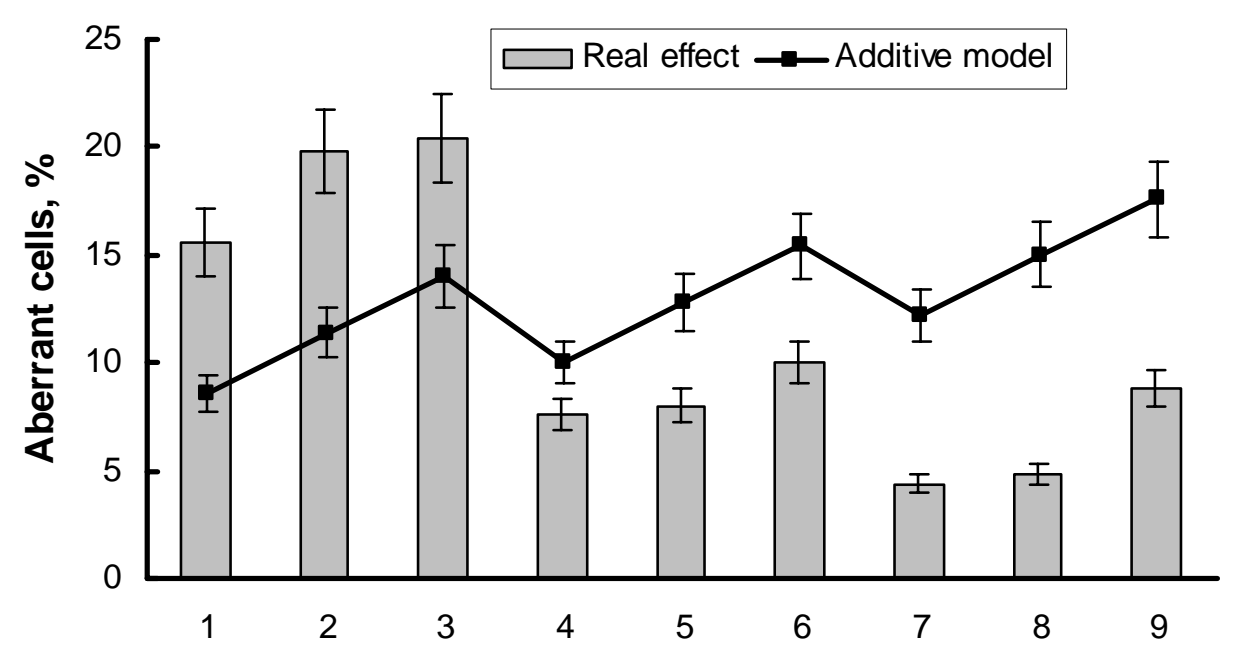

Figure 2. Cytogenetic disturbances yield in intercalar meristem of spring barley in conditions of combined soil pollution by Cs-137 and Cd

$1-1.48 \mathrm{MBq} / \mathrm{m}^{2}+2 \mathrm{mg} / \mathrm{kg} ; 2-1.48 \mathrm{MBq} / \mathrm{m}^{2}+10 \mathrm{mg} / \mathrm{kg} ; 3-1.48 \mathrm{MBq} / \mathrm{m}^{2}+50 \mathrm{mg} / \mathrm{kg} ;$ $4-7.4 \mathrm{MBq} / \mathrm{m}^{2}+2 \mathrm{mg} / \mathrm{kg} ; 5-7.4 \mathrm{MBq} / \mathrm{m}^{2}+10 \mathrm{mg} / \mathrm{kg} ; 6-7.4 \mathrm{MBq} / \mathrm{m}^{2}+50 \mathrm{mg} / \mathrm{kg}$;

$7-14.8 \mathrm{MBq} / \mathrm{m}^{2}+2 \mathrm{mg} / \mathrm{kg} ; 8-14.8 \mathrm{MBq} / \mathrm{m}^{2}+10 \mathrm{mg} / \mathrm{kg} ; 9-14.8 \mathrm{MBq} / \mathrm{m}^{2}+50 \mathrm{mg} / \mathrm{kg}$.

\section{LONG-TERM CHRONIC ECOTOXICAL EFFECTS}

One of the key questions and present gaps concerns long-term ecotoxical effects induced by chronic low dose-rate and multi-pollutant exposure at contaminated sites. Actually, few studies exist that are directly relevant to revealing the responses of plant and animal populations to radionuclides in their natural environments. In 1987-1989 an experimental study on the cytogenetic variability in three successive generations of winter rye and wheat, grown at four plots with different levels of radioactive contamination, was carried out within the 10-km ChNPP zone [7]. A dose on a growing point varied within the limits of 18-717 cGy between plots for a vegetative season 1987-1988, and within the limits of 11-417 cGy for 1988-1989. Fig. 3 shows that in autumn of 1989, aberrant cell frequencies in leaf meristem of winter rye and wheat of the second and third generations significantly exceeded these parameters for the first generations. The distinctions between cytogenetic indices obtained for the second and third generations were small and statistically insignificant, so, the observed effect is of a threshold character. It is important that cytogenetic disturbances were analyzed within the intercalar meristem of plants. It means that the overwhelming majority of radiation-induced alterations accumulated during the previous vegetative season were realized into mutations long before the samples were fixed for the cytogenetic analysis. In autumn of 1989, plants of all three generations were developing in identical conditions and were exposed to the same doses so that the most probable explanation of the registered phenomenon relates to a genome destabilization in plants grown from radiation-affected seeds. From these viewpoints, the results observed in that study and indicating a threshold character of the genetic instability induction may be a sign of a cytogenetic adaptation beginning, that is, the chronic low-dose irradiation appears to be an ecological factor creating preconditions for possible changes in the genetic structure of a population. 


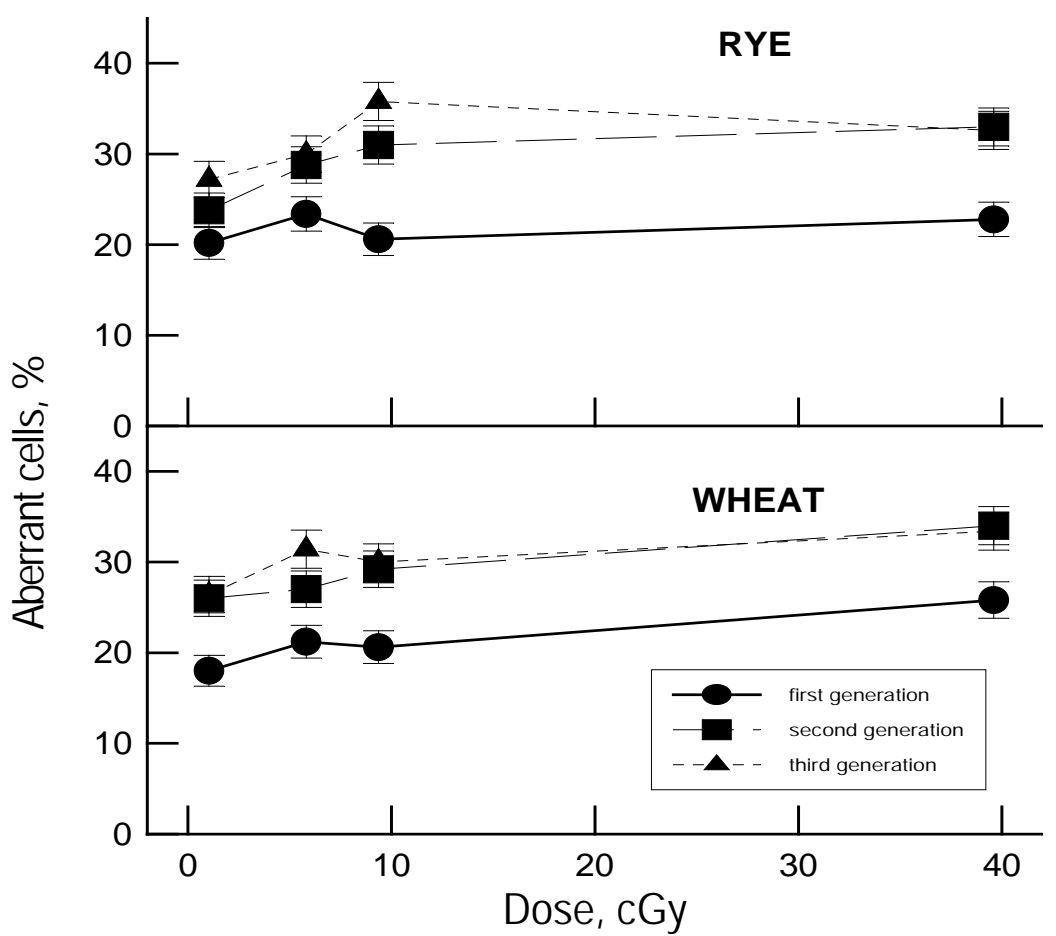

Figure 3. Yield of aberrant cells frequency in three successive generations of winter rye and wheat, grown on contaminated plots.

Plants are particularly exposed to environmental pollutants since they are stationary and unable to leave the contaminated zone; thus they cannot avoid harmful influences and must adapt to life in a harsh environment. An adaptation process in plant populations experiencing man-caused exposure was investigated in our long-term study [8]. The Scots pine populations growing in the vicinity of a radioactive waste storage facility and at sites with differing levels of radioactive contamination in the 30-km Chernobyl NPP zone were characterized (Fig. 4) by a pronounced increased level of cytogenetic disturbances over the observation period of 1997-2002. An analysis of the mutations spectrum shows that chemical mutagens comprise the main contribution to the environmental contamination in the vicinity of the radioactive waste storage facility in contrast to the influence of ionising radiation in the $30-\mathrm{km}$ Chernobyl zone. A portion of the seeds from reference and impacted populations was subjected to a subsequent acute $\gamma$-ray exposure. The seeds from the Scots pine populations that are experiencing a man-caused impact showed (Fig. 5) higher resistance than the reference one. As a corollary of this, a sharp distinction in the increments of cytogenetic disturbances between the reference and anthropogenically influenced Scots pine populations induced by acute radiation was observed. The acute $\gamma$-rays dose of 15 Gy increased the cytogenetic disturbances level 11 times in the reference population, while exposure of the seeds from impacted sites to the same dose changed the corresponding values only 2 times approximately. There is convincing proof [9] that the divergence of populations in terms of radioresistance is connected with a selection for changes in the effectiveness of the repair systems. The Scots pine populations experiencing anthropogenic exposure showed a significantly increased level of cytogenetic variability in comparison to the reference one. Taken together with a higher radioresistance of the Scots pine seeds, these findings suggest that there are adaptation processes in the experiencing man-caused influence pine populations. Consequently, an appearance of some standing factors (either of natural origin or man-made) in the plants environment activates genetic mechanisms, changing a population's resistance to this exposure. 


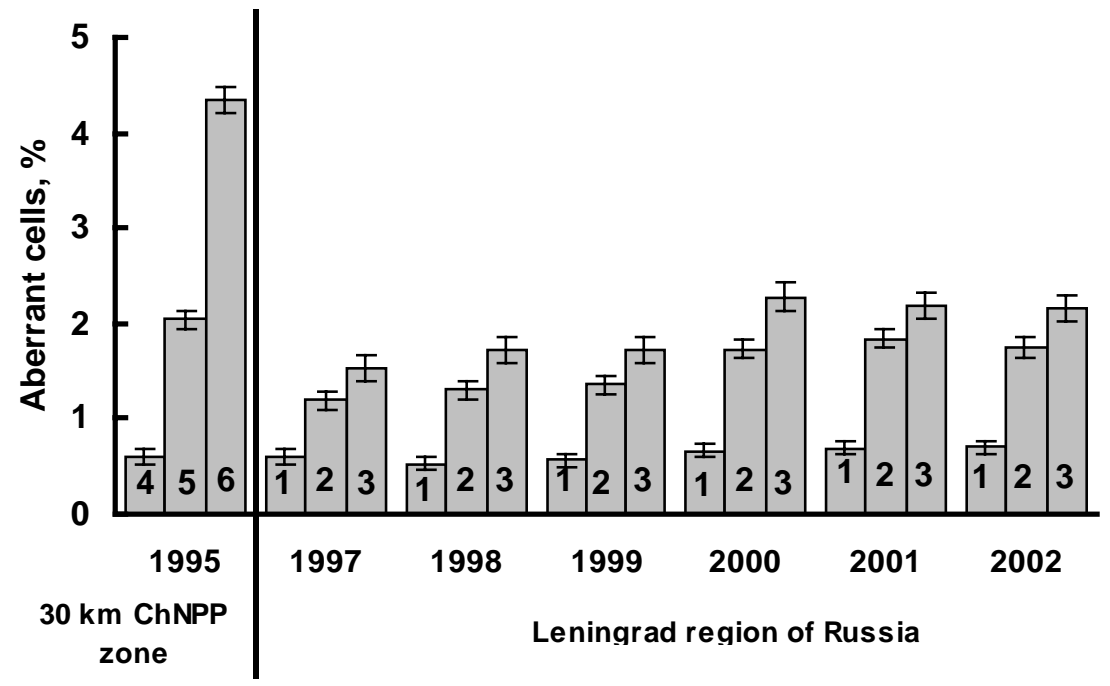

Figure 4. Aberrant cell frequency (\%) in root meristem of Pinus sylvestris L. seedlings from $30 \mathrm{~km}$ Chernobyl NPP zone (1995) and Leningrad region of Russia (1997-2002).

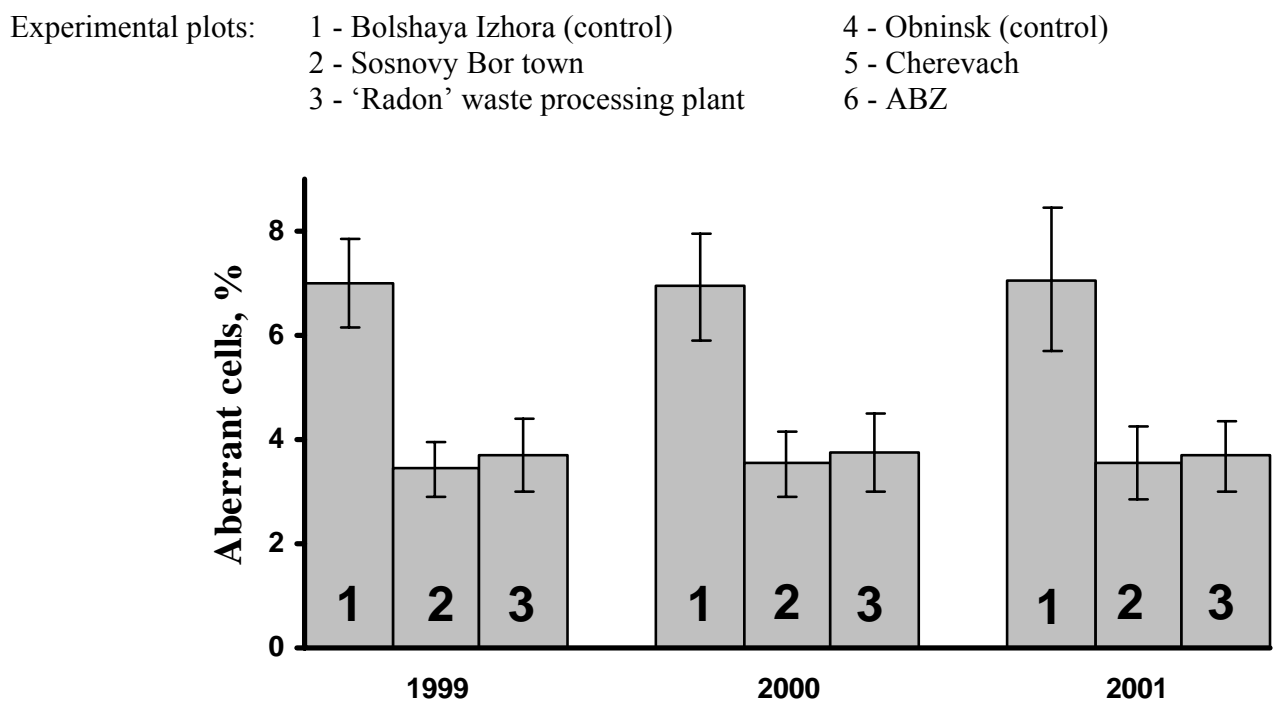

Figure 5. Aberrant cell frequency in root meristem of Scots pine seedlings grown from seeds sampled in Leningrad region in 1999-2001 and exposed to an acute $\gamma$-ray dose of $15 \mathrm{~Gy}$.

1 - Bolshaya Izhora, 2 - Sosnovy Bor, 3 - 'Radon’ LWPE

\section{CONCLUSION}

Quantifying and reducing an impact of ionizing radiation on environment require a comprehensive understanding of the ecological consequences of exposure. Therefore, an actuality and severity of ecotoxical effects within areas affected by low doses and multi-pollutant exposure are among key problems today. Genetic nature of such effects, as well as their dynamics in progeny remains 
inadequately explored up to now. It is a very important one, but is also the most neglected topic. Our findings suggest that the further evolution of investigations in ecotoxicology would issue in the development of a theoretical bases and practical procedures for environmental protection against radioactivity, taking into account the new experimentally confirmed facts about the presence of such essentially important patterns of the biological effect of low ionizing radiation doses as the nonlinearity of a dose-effect relationship, radiation-induced genomic instability, phenomenon of radioadaptation, increased probability of synergetic and antagonistic effects of the combined action of different factors. A development of a new concept of radiation protection for human and biota should be based on a clear understanding of these effects and their contribution to biological response. This should be addressed in the future.

\section{References}

[1] Geras'kin S.A., Koz'min G.V., Russian Journal of Ecology 26 (1995) 389 - 393.

[2] Theodorakis C.W., Blaylock B.G., Shugart L.R., Ecotoxicology 6 (1997) 205-218.

[3] Geras'kin S.A., Radiat. Biol. Radioecol. 35 (1995) 563-571. (in Russian).

[4] Geras'kin S.A., Dikarev V.G., Dikareva N.S., Radiat. Biol. Radioecol. 42 (2002) 369-383. (in Russian).

[5] Evseeva T.I., Geras'kin S.A., Shuktomova I.I., J. Environ. Radioactivity 68 (2003) 235-248.

[6] Evseeva T.I., Geras'kin S.A., Shuktomova I.I., Taskaev A.I., J. Environ. Radioactivity submitted for publication.

[7] Geras'kin S.A., Dikarev V.G., Zyablitskaya Ye.Ya. et al., J. Environ. Radioactivity. 66 (2003) 155-169.

[8] Geras'kin S.A., Zimina L.M., Dikarev V.G. et al., J. Environ. Radioactivity. 66 (2003) 171-180.

[9] Shevchenko V.A., Pechkurenkov V.L., Abramov V.I., Radiation genetics of natural populations: genetic consequences of the Kyshtym accident (Nauka, Moscow, 1992) 221 p. (in Russian). 